\title{
Pengaruh Slow Stroke Back Massage Terhadap Kualitas Tidur Ibu Post Sectio Caesarea di RS. Bhayangkara Bengkulu
}

\author{
Anninah $^{1 *}$, Asmawati ${ }^{2}$, Sariman Pardosi ${ }^{3}$ \\ ${ }^{1}$ Prodi DIV Keperawatan, Poltekkes Kemenkes Bengkulu, Bengkulu, Indonesia \\ 2,3Jurusan Keperawatan, Poltekkes Kemenkes Bengkulu, Bengkulu, Indonesia \\ *anninah23@gmail.com
}

\begin{abstract}
Mother with sectio caesarea needs sleep for recovery and treatment. Mother with sleep disorders have a negative impact on quality of maternal health. Purpose of this research to determined effect of slow stroke back massage on quality of post-sectio caesarea mother's sleep. This study used quasy experimental with pre-test and post-test with control group design. Samples were taken mother with sectio caesarea at RS. Bhayangkara Bengkulu with 2 groups of consecutive sampling technique and each group obtain 15 respondents. The analysis used independent sample t-test at $\alpha<5 \%$. The result of intervention group and control group before being given a slow stroke back massage were each average of sleep quality scores 10.27 and 8.00, meanwhile the result of intervention group and control group after being given a slow stroke back massage were each average of sleep quality scores 8.80 and 7.60. The slow stroke back massage teraphy need to restore the quality of post-sectio caesarea mother's sleep in RS. Bhayangkara Bengkulu.
\end{abstract}

Keywords: sectio caesarea, slow stroke back massage, quality sleep

\begin{abstract}
Abstrak
Ibu post sectio caesarea membutuhkan tidur untuk pemulihan kondisi tubuh dan memaksimalkan perawatan. Gangguan tidur dapat menimbulkan masalah kesehatan bagi ibu. Riset ini bertujuan untuk mengetahui pengaruh slow stroke back massage terhadap kualitas tidur ibu post sectio caesarea. Penelitian ini menggunakan pendekatan quasi eksperimen dengan pre-test and post-test with control group design. Sampel yang diambil adalah ibu post partum dengan tindakan sectio caesarea di RS. Bhayangkara Bengkulu dengan teknik consecutive sampling yang dialokasikan ke dalam dua kelompok masing-masing 15 responden. Analisis statitik menggunakan independent sample t-test $\alpha<5 \%$. Sebelum diberikan slow stroke back massage diperoleh hasil masing-masing rerata skor kualitas tidur pada kelompok intervensi sebesar 10,27 dan pada kelompok kontrol sebesar 8,00. Setelah diberikan slow stroke back massage pada kelompok intervensi diperoleh rerata skor kualitas tidur sebesar 8,80 dan kelompok kontrol 7,60 (p value 0.03). Terapi slow stroke back massage diperlukan untuk memperbaiki kualitas tidur ibu pasca sectio caesarea di RS Bhayangkara Bengkulu.
\end{abstract}

Kata kunci: sectio caesarea, slow stroke back massage, kualitas tidur

Jurnal Keperawatan Raflesia, Volume 2 Nomor 1, Mei 2020

ISSN: (p) 2656-6222, (e) 2657-1595, DOI 10.33088/jkr.v2i1.427

Available online: https://jurnal.poltekkes-kemenkes-bengkulu.ac.id/index.php/jkr 


\section{PENDAHULUAN}

Ibu post partum membutuhkan istirahat dan tidur lebih lama minimal 8 jam untuk memulihkan keadaannya setelah melahirkan dan memaksimalkan perawatan Bahiyatun (2009). Secara umum ibu post partum sering mengalami gangguan tidur. Menurut Safrudin, Asrin dan Purwatiningsih (2009) tidur yang terganggu dapat menyebabkan regenerasi sel tubuh tidak maksimal, dampaknya pada tubuh akan menjadi lemas dan rentan terhadap penyakit.

Berdasarkan hasil Survei Demografi dan Kesehatan Indonesia (SDKI) pada tahun 2012 dapat diketahui bahwa sekitar 460/100.000 kelahiran hidup terdapat ibu post partum yang mengalami gangguan istirahat tidur. Hasil penelitian Fitri, Trisyani, dan Maryati (2012) di RSUD Sumedang menunjukkan bahwa $85.7 \%$ ibu post partum dengan Sectio Caesarea (SC) memiliki kualitas tidur buruk. Kualitas tidur yang buruk pada ibu post partum disebabkan beberapa faktor diantaranya nyeri, ketidaknyamanan pada kandung kemih, gangguan bayi (Marmi, 2014), ketegangan otot dan pembengkakan payudara (Murray \& McKinney, 2007).

Kualitas tidur ibu post partum yang buruk menimbulkan berbagai dampak negatif pada pemulihan kondisi ibu setelah masa post partum diantaranya adalah berkurangnya jumlah air susu ibu, memperlambat proses involusi uterus, menimbulkan depresi, ketidakmampuan dalam merawat bayi dan dirinya sendiri (Suhana, 2010), insomnia kronis yang menyebabkan rasa kantuk pada siang hari, penurunan kognitif, kelelahan dan cepat marah (Dorheim et al., 2009). Kualitas tidur yang buruk juga dapat berdampak negatif terhadap pekerjaan ibu, kehidupan keluarga dan hubungan sosial (Khayamim, Bahadoran, \& Mehrabi, 2016).

Metode yang digunakan dalam menangani kualitas tidur buruk dapat berupa terapi farmakologi ataupun terapi nonfarmakologi. Pada populasi umum, obat tidur seringkali digunakan untuk mengobati insomnia dan memperpanjang durasi tidur, namun hal ini tidak direkomendasikan untuk wanita dengan pasca persalinan yang sedang menyusui (Della-Giustina \& Chow, 2003). Hal ini dikarenakan dapat mempengaruhi produksi ASI dan dapat membatasi kemampuan ibu untuk menanggapi kebutuhan bayi. Peningkatan istrahat tidur pada ibu sangat penting untuk mengurangi terjadinya peningkatan stress, ibu harus dibantu agar dapat beristirahat dengan baik sesuai dengan tingkat kebutuhan istirahat tidur. Salah satu cara yang dapat digunakan yaitu dengan teknik nonfarmakologis berupa relaksasi.

Terapi Slow Stroke Back Massage (SSBM) ini merupakan salah satu bentuk terapi relaksasi masase punggung yang dapat digunakan untuk mengatasi gangguan tidur dengan cara mengusap kulit dengan lembut secara perlahan dan berirama dengan kecepatan tangan 60 kali usapan per menit (Potter dan Perry, 2005) yang dapat memperbaiki kualitas tidur ibu dan meningkatkan kenyamanan pada klien (Caldwell et al., 2003). 
Hasil penelitian menunjukkan bahwa SSBM efektif untuk meningkatkan kualitas tidur pasien insomnia. Penelitian yang telah dilakukan oleh Shinde dan Anjum (2014) menunjukkan SSBM yang diberikan selama 3 hari terbukti efektif meningkatkan kualitas tidur pasien yang dirawat di ICU. Berdasarkan penelitian Melastuti dan Avianti (2014) didapatkan SSBM berpengaruh untuk meningkatkan kualitas tidur pasien post operasi di RSI Sultan Agung Semarang. Hasil penelitian Cinar dan Eser (2012) menyatakan terjadi peningkatan kualitas tidur pada lansia setelah dilakukan SSBM selama 3 hari. Selain itu, SSBM telah diteliti sebagai tindakan perawatan mandiri dalam menangani masalah low back pain di Indonesia (Husnaa \& Dewi, 2012).

Hasil studi awal pendahuluan yang dilakukan peneliti terhadap 5 orang ibu post partum dengan tindakan Sectio Caesarea didapatkan 5 (100\%) ibu post SC mengalami nyeri sehingga tidak bisa tidur, sering mengantuk pada siang hari, dan mengalami kesulitan memulai tidur. Hasil wawancara terhadap salah satu perawat di ruang Melati diketahui belum pernah dilakukan terapi SSBM untuk meningkatkan kualitas tidur ibu post SC. Berdasarkan uraian diatas, meningkatkan keinginan peneliti melakukan penelitian mengenai pengaruh SSBM terhadap peningkatan kualitas tidur Ibu post Sectio Caesarea.

\section{METODE}

Desain penelitian ini melalui pendekatan quasi eksperimental dengan pre-test and post-test with control group. Tujuan penelitian adalah untuk melihat perbedaan rerata kualitas tidur ibu pasca SC yang diberikan SSBM. Sampel adalah ibu pasca SC yang dirawat di RS Bhayangkara Kota Bengkulu dan dibagi dalam 2 kelompok masing-masing 15 orang dan total sampel berjumlah 30 orang. Sampel kelompok intervensi diberikan terapi SSBM sebanyak 1 kali sehari selama 15 menit selama 3 hari berturut-turut dan kelompok kontrol diberikan edukasi SSBM selama 1 kali pertemuan selama 20-30 menit menggunakan media leaflet.

Tempat penelitian dilakukan di ruang Melati RS Bhayangkara Bengkulu yang dilaksanakan pada bulan Januari-Juni 2018. Teknik yang digunakan adalah konsekutif sampling yaitu memilih sampel yang memenuhi kriteria penelitian sampai jumlah sampel terpenuhi. Sampel yang dipilih yakni ibu pasca SC 6 jam, usia 2035 tahun, pendidikan minimal tamat SD, belum pernah mendapat terapi SSBM. Instrumen penelitian yang dipakai yaitu The Groningen Sleep Quality Scale (GSQS) yang telah digunakan untuk mengukur kualitas tidur pada penelitian Kristanto (2012) dengan koefisien reliabilitas (Cronbach's Alpha) 0,85. Kuesioner GSQS berisi 14 pertanyaan dengan rentang skor 014. Semakin besar skor GSQS maka semakin buruk kualitas tidur ibu dan sebaliknya. Kualitas tidur dapat dikategorikan baik apabila skor GSQS kurang dari atau sama dengan $\leq 2$ (Morad et al, 2009). 
HASIL

Tabel 1. Karakteristik Responden dan Kesetaraan Variabel Penelitian $(n=30)$

\begin{tabular}{lccc}
\hline \multirow{2}{*}{ Variabel } & \multicolumn{2}{c}{ Kelompok } & P value \\
\cline { 2 - 4 } Usia & Intervensi & Kontrol & \\
$\quad$ Mean & 27,73 & 28,33 & 0,061 \\
$\quad$ Median & 28 & 29 & \\
SD & 5,311 & 3,519 & \\
$\quad$ Min-Max & $20-35$ & $20-34$ & \\
CI for Mean & $25,00-$ & $26,47-$ & \\
$\quad$ 95\% & 30,36 & 29,92 & \\
Pendidikan & & & \\
SD & $4(26,7 \%)$ & $7(46,7 \%)$ & 0,524 \\
SMP & $4(26,7 \%)$ & $3(20,0 \%)$ & \\
SMA & $7(46,7 \%)$ & $5(33,3 \%)$ & \\
PT & $0(0,0 \%)$ & $0(0,0 \%)$ & \\
& & & \\
Pekerjaan & & & \\
IRT & $9(60 \%)$ & $11(73,3 \%)$ & 0,439 \\
Wiraswasta & $6(40 \%)$ & $4(26,7 \%)$ & \\
& & &
\end{tabular}

Tabel 1 didapatkan karakteristik responden berdasarkan usia. Pada kelompok intervensi ditemukan rentang usia responden berada pada rentang 20-35 tahun dengan rerata usia 27,73 tahun dan di kelompok kontrol usia berada pada rentang 20-34 tahun dengan rerata 28,33 tahun. Riwayat pendidikan terakhir ibu terbanyak pada keompok intervensi adalah SMA $(46,7 \%)$ sedangkan pada kelompok kontrol memiliki adalah SD (46,7\%). Sebagian besar (60\%) responden kelompok intervensi dan kelompok kontrol $(73,3 \%)$. adalah ibu tidak bekerja.

Tabel 2. Gambaran Kualitas Tidur Ibu Selama hamil dan Kesetaraan $(n=30)$

\begin{tabular}{lccl}
\hline Variabel & \multicolumn{2}{c}{ Kelompok } & \\
\cline { 2 - 3 } Kualitas Tidur & Intervensi & Kontrol & P value \\
\hline Mean & 10,27 & 8,00 & \\
Median & 10 & 8 & \\
Min-max & $8-13$ & $4-10$ & \\
SD & 1,335 & 1,648 & $0,733^{*}$ \\
SE & 0,345 & 0,425 & \\
C1 for Mean & $9,63-10,94$ & $7,20-8,83$ & \\
95\% & & & \\
\hline Sign* $\alpha>0.05$, t independent &
\end{tabular}

Tabel 2 menunjukkan hasil rerata skor kualitas tidur ibu sebelum persalinan pada kelompok intervensi lebih tinggi (buruk) didapatkan yaitu 10,27 dibanding pada kelompok kontrol yaitu 8,0.

Hasil uji kesetaraan didapatkan $p$ value $>\alpha$ 0,05 yang menunjukkan bahwa karakteristik responden dan rerata kualitas tidur antar kelompok adalah setara sebelum dilakukan intervensi.

\section{Tabel 3. Perbedaan Rerata Kualitas Tidur Ibu Pasca Sectio Caesarea $(\mathrm{n}=30)$}

\begin{tabular}{|c|c|c|c|c|}
\hline \multirow{2}{*}{$\begin{array}{l}\text { Variabel } \\
\text { Kualitas } \\
\text { tidur }\end{array}$} & \multicolumn{2}{|c|}{ Kelompok } & \multirow{2}{*}{$\begin{array}{l}p \text { value } \\
\text { (within } \\
\text { group) }\end{array}$} & \multirow{2}{*}{$\begin{array}{c}p \text { value } \\
\text { (between } \\
\text { group) }\end{array}$} \\
\hline & Intervensi & Kontrol & & \\
\hline \multicolumn{5}{|l|}{ Pre SSBM } \\
\hline Mean & 10,27 & 8,00 & & \\
\hline Median & 10 & 8 & & \\
\hline Min-maks & $8-13$ & $4-10$ & $0.001 *$ & \\
\hline SD & 1,335 & 1,648 & & \\
\hline CI for & $0,345:$ & $0,425:$ & & \\
\hline Mean $95 \%$ & 10,94 & 8,83 & & $0,003 * *$ \\
\hline \multicolumn{5}{|l|}{ Post SSBM } \\
\hline Mean & 8,80 & 7,60 & & \\
\hline Median & 9 & 8 & 0.009 & \\
\hline Min-maks & 1,320 & 1,549 & & \\
\hline SD & 0,341 & 0,400 & & \\
\hline $\mathrm{CI}$ & 9,19: & 6,83 & & \\
\hline Mean $95 \%$ & 9,47 & 8,33 & & \\
\hline
\end{tabular}

Tabel 3 menggambarkan rerata skor kualitas tidur ibu sebelum dilakukan intervensi pada masing-masing adalah 10,27 (kelompok intervensi) dan 8,00 (kelompok kontrol). Sesudah dilakukan intervensi pada kelompok didapatkan hasil rerata skor kualitas tidur pada kelompok intervensi turun yakni 8,80 dan pada kelompok kontrol adalah 7,60. Hasil uji $t$ paired didapat $p$ value 0,0001 yang berarti ada perbedaan rerata skor kualitas tidur sesudah diberikan intervensi keperawatan SSBM dalam kelompok intervensi, sedangkan dalam kelompok kontrol $p$ value 0,009 yang berarti ada perbedaan rerata 
kualitas tidur sesudah diberikan intervensi keperawatan edukasi SSBM dengan leaflet. Hasil independen t-test menunjukkan $p$ value $0,003(\mathrm{p} \leq \alpha=0,05)$ dan disimpulkan ada perbedaan rerata skor kualitas tidur ibu pasca SC setelah diberikan terapi slow stroke back massage selama 3 hari antar kelompok tersebut.

Tabel 4. Selisih Peningkatan Rerata Kualitas Tidur Sebelum dan sesudah SSBM $(\mathbf{n}=30)$

\begin{tabular}{lllll}
\hline Variabel & $\begin{array}{l}\text { diff } \\
\text { mean }\end{array}$ & SE & CI 95 \% & $\begin{array}{l}P \\
\text { value }\end{array}$ \\
\hline $\begin{array}{l}\text { Kualitas } \\
\text { tidur }\end{array}$ & 1.69 & 0.752 & $0.06: 3.140$ & $0.042^{*}$ \\
\hline Sign* p value $\leq \alpha$ & 0.05, t independent & \\
\hline
\end{tabular}

Dari tabel 4 dapat dilihat bahwa perbedaan rerata penurunan skor kualitas tidur antar kelompok sebesar 1.69 dan 95\% diyakini bahwa rata-rata penurunan skor sebesar 0.063.140. Disimpulkan bahwa intervensi SSBM dapat meningkatkan rerata kualitas tidur sebesar 1.69 ( $\mathrm{p}$ value 0.042 )

\section{PEMBAHASAN}

Hasil analisis menggambarkan rerata skor kualitas tidur ibu yang diukur 6 jam pasca SC pada kelompok intervensi dan kelompok kontrol lebih tinggi yang dapat diartikan bahwa kualitas tidur ibu beberapa minggu sebelum persalinan buruk.

Sebagian besar ibu mengalami kualitas tidur yang buruk. Buruknya kualitas tidur ibu hamil merupakan masalah yang lazim terjadi dan sering dilaporkan terutama trimester tiga kehamilan. Studi menemukan bahwa 82-98\% ibu pada trimester akhir kehamilan melaporkan bahwa terbangun malam hari dan $64-86 \%$ mengalami masalah kualitas tidur selama kehamilan (Hutchison et al., 2012). Hasil penelitian menunjukkan bahwa rata-rata jumlah jam tidur ibu hamil menurun di trimester tiga kehamilan sebanyak 7.5 jam dan hanya 29 $\%$ ibu hamil yang memiliki kualitas tidur yang sangat baik pada trimester akhir kehamilan

Hasil uji statistik didapatkan ada perbedaan rerata kualitas tidur pada masing-masing kelompok sebeum dan setelah diberikan slow stroke back massage ataupun diberikan edukasi SSBM menggunakan leaflet. Rerata skor kualitas tidur pada kedua kelompok sama-sama menurun setelah diberikan intervensi. Namun ada perbedaan penurunan rerata skor kualitas tidur setelah intervensi SSBM lebih besar yaitu 2.27 poin sedangkan pada kelompok non intervensi sebesar 1.2 poin.

Perubahan kualitas tidur yang dijumpai dalam penelitian ini dapat disebabkan karena beberapa faktor yang mempengaruhi kualitas tidur ibu seperti adanya nyeri post sectio caesarea, ketidaknyamanan pada kandung kemih, gangguan bayi (Marmi, 2014), ketegangan otot dan pembengkakan payudara (Murray dan McKinney, 2007).

Hasil ini sejalan dengan (Shinde \& Anjum, 2014) dalam penelitiannya menemukan bahwa SSBM terbukti efektif dalam meningkatkan kualitas tidur pasien ICU setelah tindakan slow stroke back massage selama 3 hari. Riset Melastuti dan Avianti (2014) di RSI Sultan Agung Semarang menunjukkan bahwa SSBM berpengaruh terhadap kualitas tidur pasien post operasi. (Cinar \& Eser, 2012) menyatakan terjadi peningkatan kualitas tidur lansia setelah mendapatkan terapi perlakuan berupa SSBM selama 3 hari dan mengalami perbaikan dalam kualitas tidurnya. 
Terapi SSBM lebih baik meningkatkan kualitas tidur dibandingkan dengan pemberian edukasi menggunakan leaflet. Melalui pemberian terapi SSBM terjadi proses pemberian stimulus pada kulit yang akan berdampak pada pengurangan kualitas nyeri, Proses ini bekerja dengan cara pelepasan endorphin yang terjadi akibat pemberian stimulus pada kulit, sehingga akan terjadi proses blok terhadap penyampaian ransangan nyeri. Selain itu, dengan aktifnya hantaran serabut saraf sensori A-beta yang lebih besar dan lebih cepat akan mempercepat proses penurunan hantaran nyeri melalui serabut tipe $\mathrm{C}$ dan A-delta yang memiliki diameter lebih kecil yang akan menutup gerbang sinap untuk transmisi impuls nyeri secara sekaligus (Potter dan Perry, 2005).

SSBM yang dilakukan dengan durasi 15 menit akan mengakibatkan terjadinya proses dilatasi pada pori-pori kulit yang akan menyebabkan tubuh kehilangan panas sehingga terjadi suhu tubuh menurun yang akan mengurangi fase keterjagaan. Menurut Cinar, Eser, dan Khorshid (2009), massage punggung selama 15 menit dan 30 menit.efektif dalam penurunan panas tubuh secara signifikan. Arjunam (2011) menyatakan bahwa manusia memiliki ritme sirkardian atau ritme suhu tubuh yang tidak menetap $37^{\circ} \mathrm{C}$ (suhu bisa naik dan turun), ketika suhu tubuh terjadi penurunan maka tubuh akan mengalami kelelahan, rasa malas dengan output lebih cepat tertidur.

Pemberian terapi slow stroke back massage dengan memanfaatkan jam tidur secara efektif memiliki dampak pada pemenuhan energi. Potter (2005) mengemukakan bahwa selama tidur tubuh akan menyimpan energi dan laju metabolik basal menurun dan menyimpan persediaan energi. Pada waktu awal tidur malam hari ada proses peningkatan sekresi growth hormon (GH) dan penurunan Adeno Corticotropin Hormon (ACTH) serta kortisol (A.Steiger, 2003). Kortisol akan memecah karbohidrat, protein dan lemak melalui proses gluconeogenesis yang menghasilkan sumber energi berupa glukosa yang berfungsi untuk memperbaiki fungsi tubuh selama periode istirahat (Smeltzer \& Bare, 2002).

Rerata kualitas tidur pada kelompok kontrol menunjukkan penurunan rerata skor kualitas tidur lebih kecil dibandingkan dengan kelompok intervensi yakni sebesar 1,2 poin. Faktor ini kemungkinan dapat disebabkan ibu pada kelompok kontrol hanya diberikan edukasi slow stroke back massage dan keluarga pasien diminta melakukan intervensi SSBM secara mandiri. Ketidaktahuan keluarga dan tidak ada pengalaman dalam penggunaan teknik SSBM yang kurang tepat akan menghasilkan output yang kurang. Selain itu, dapat dilihat dari faktor pendidikan responden pada kelompok kontrol sebagian besar responden adalah SD (46,7\%). Pendidikan menentukan sulit atau mudahnya seseorang dalam proses penyerapan informasi, memahami dan memperoleh pengetahuan. Menurut Notoatmojo (2007) seseorang dengan tingkat pendidikan yang tinggi akan semakin mudah menerima berbagai informasi sehingga makin banyak pengetahuan yang dimilikinya.

Hasil riset ini membuktikan bahwa pemberian slow stroke back massage hanya sedikit efektif menurunkan rerata skor kualitas tidur pada ibu post sectio caesarea di RS Bhayangkara Bengkulu. Intervensi 
SSBM belum bisa meningkatkan kualitas tidur lebih baik.

Berbagai faktor yang menyebabkan ibu post partum mengalami gangguan tidur adalah disebabkan gangguan tidur yang dialami sebelumnya selama kehamilan. Dari data menunjukkan rata-rata skor kualitas tidur masih tinggi 10,2 (skor tidur buruk). Menurut Pires, Andersen, Giovenardi, \& Tufik (2010) perubahan tidur selama kehamilan terutama berkurangnya tidur REM pada trimester akhir disebabkan karena peningkatan bertahap konsentrasi hormone progesterone dan estrogen. Hormon yang berhubungan dengan kehamilan dan persalinan ini memiliki kemampuan untuk menurunkan tidur REM.

Secara statistik SSBM dapat meningkatkan kualitas ibu post partum SC. Hal ini sesuai dengan penelitian (Ko \& Lee, 2014) menunjukkan bahwa ada perbedaan nilai rerata kualitas tidur pada kelompok yang diberikan SSBM 1 kali sehari durasi 20 menit selama 5 hari dibanding yang tidak diberikan masase punggung. Ibu yang diberikan SSBM menurun nilai rerata kualitas tidur sebesar 4,87 poin dibandingkan ibu yang tidak diberikan SSBM sebesar 0.9 poin pada hari ke-14 post partum.

Salah satu kurang berhasilnya terapi SSBM dikarenakan pemberian terapi SSBM dilakukan oleh peneliti yang belum memiliki sertifikasi keahlian dalam melaksanakan terapi. Selain itu, nilai rerata skor tidur pasien yang tinggi atau kualitas tidur yang buruk juga mempengaruhi keberhasilan terapi. Selain itu, faktor lingkungan rumah sakit juga mempengaruhi kualitas tidur ibu post SC.
Rumah sakit Bhayangkara yang memiliki akses kunjungan mudah dan kurang pembatasan jam besuk dan lokasi rumah sakit yang terlalu dekat dengan jalan raya. Serta ruang bangsal perawatan yang diisi dengan 3-4 orang pasien dalam 1 ruangan mempengaruhi kemampuan ibu untuk tertidur. Selain faktor di atas, adanya nyeri luka operasi, aktifitas menyusui malam hari, ketidaknyamanan serta rewelnya bayi terutama malam hari.

\section{KESIMPULAN}

Perbedaan peningkatan kualitas tidur setelah diberikan intervensi slow stroke back massage sebesar 1,69 lebih tinggi dibandingkan dengan kelompok yang diberikan edukasi menggunakan leaflet. Ada perbedaan kualitas tidur antar kelompok intervensi dan kelompok kontrol (p value 0,042). Terapi Slow stroke back massage sedikit efektif untuk meningkatkan kualitas tidur pada ibu post sectio caesarea. Hal ini berimplikasi bahwa slow stroke back massage dapat dijadikan sebagai alternatif terapi yang dapat digunakan oleh penanganan kualitas tidur yang buruk pada ibu post sectio caesarea.

Hasil penelitian ini belum bisa menggeneralisasi hasil penelitian lainnya. Intervensi slow stroke back massage belum bisa dikatakan dapat meningkatkan kualitas tidur pada seluruh ibu post sectio caesarea. Bagi peneliti selanjutnya diharapkan untuk meneliti variabel perancu terhadap kualitas tidur ibu post sectio caesarea.

\section{DAFTAR PUSTAKA}

A.Steiger. (2003). Sleep and endocrinology. Journal of Internal Medicine, 254(13), 13-22. https://doi.org/10.1016/B978-14557-4975-1.00068-1. 
Bahiyatun. (2009). Asuhan kebidanan nifas normal. Jakarta: EGC.

Cadwell, E \& Hegner, B . (2003). Asisten keperawatan: Suatu pendekatan proses keperawatan. Edisi 6. Jakarta: EGC.

Cinar, Ş., \& Eser, I. (2012). Effect on sleep quality of massage effect on sleep quality of back massage in older adults in rest home*. Dokuz Eylül Üniversitesi Hemşirelik Yüksekokulu Elektronik Dergisi, 5(1), 2-7. Retrieved from http://www.deuhyoedergi.org.

Cinar, S., Eser, I., \& Khorshid, L. (2009). The effects of back massage on the vital signs and anxiety level of elderly staying in a rest home. Hacettepe Üniversitesi Hemşirelik Fakültesi Dergisi, 16(2), 1421.

Della-Giustina, K., \& Chow, G. (2003). Medications in pregnancy and lactation. Emergency Medicine Clinics of North America, 21(3), 585-613. https://doi.org/10.1016/S07338627(03)00037-3.

Dorheim, K., Bondevik, G., Eberhard, G., Bjorvatn, B. (2009). Sleep and depression in postpartum women: A population-based study. US: US National Library of Medicine National Institute of Health. 2017. http://www.ncbi.nlm.nih.gov/pmc/articl es/PMC2704916/. Diakses pada 3 September 2017.

Fitri, M., Trisyani, M., \& Maryati, I. (2012). Hubungan intensitas nyeri luka sectio caesarea dengan kualitas tidur pada pasien post partum hari ke-2 di ruang rawat inap rsud sumedang. Milla Fitri Fakultas Ilmu Keperawatan Universitas Padjadjaran (Jl. Raya Bandung Sumedang KM, 21, 1-14.

Husnaa, G. S., \& Dewi, N. S. (2012). the Effect of slow stroke back massage (ssbm) to the change of the pain intensity in patients with acute low back pain (Lbp). Diponegoro Journal of Nursing, 1(1), 66-73.
Hutchison, B. L., Stone, P. R., McCowan, L., Stewart, A.W., Thompson, J., \& Mitchell, E. A. (2012). A postal survey of maternal sleep in late pregnancy. BMC Pregnancy and Childbirth, 12, 144.

Khayamim, N., Bahadoran, P., \& Mehrabi, T. (2016). Relationship between fatigue and sleepiness with general health of mothers in the postpartum period. Iranian Journal of Nursing and Midwifery Research, 21(4), 385. https://doi.org/10.4103/17359066.185580

Ko, Y. L., \& Lee, H. J. (2014). Randomised controlled trial of the effectiveness of using back massage to improve sleep quality among Taiwanese insomnia postpartumwomen. Midwifery, 30(1), 60-64.

https://doi.org/10.1016/j.midw.2012.11. 005

Kristanto, A. (2013). Kajian faktor-faktor risiko yang berhubungan dengan kelelahan pengemudi truk trailer di PT AMI tahun 2012. Skripsi. Universitas Indonesia

Marmi. (2014). Asuhan kebidanan pada masa nifas "peuperium care". Yogyakarta: Pustaka Pelajar

Melastuti, E., Avianti, L. (2014). Pengaruh terapi slow stroke back massage (ssbm) terhadap kualitas tidur pasien post operasi di RSI Sultan Agung Semarang. Skripsi. Universitas Islam Agung Semarang. Semarang

Murray, S, McKinney, E. (2007). Foundations of maternal-newborn nursing. $4^{\text {th }} \mathrm{Ed}$. Philippines: Elsevier

Notoatmodjo, S. (2012). Metodologi penelitian kesehatan. Jakarta: Rineka Cipta

Pires, G. N., Andersen, M. L., Giovenardi, M., \& Tufik, S. (2010). Sleep impairment during pregnancy: Possible implications on mother-infant relationship. Medical Hypotheses, 75(6), 578-582. https://doi.org/10.1016/j.mehy.2010.07. 036 
Potter \& Perry. (2005). Buku ajar fundamental keperawatan: Konsep, proses, dan praktik. Jakarta: EGC

Safrudin, Asrin, \& Purwatiningsih, E. (2009). Hubungan kualitas tidur dengan lama hari dirawat pasien gastritis di rsu kebumen. Jurnal Ilmiah Kesehatan Keperawatan, 5(2), 109-118.

Shinde, Mahadeo, \& Anjum, shabana. (2014). Effectiveness of slow back massage on quality oflnsleep among icu patient's. International Journal Of Science And Research, 3(3), 292-298. Retrieved from

httpwww.ijsr.netarchivev3i3MDIwMT

MxMTI0.pdf

Smeltzer, S., Bare, B. (2002). Buku ajar keperawatan medikal bedah brunner \& suddart Ed 8 Vol 2. Jakarta: EGC

Suhana, L.(2010). Kebutuhan dasar ibu nifas.http://blogs.unpad.ac.id/lidyasuha na /Kebutuhan-dasar-ibu-nifasPTM6.pdf. Diakses pada 30 September 2017 


\section{HALAMAN INI SENGAJA DI KOSONGKAN}

